\title{
Effectiveness of Flipped Learning: Improving Pre-Service Teachers' Prowess in Producing Videos
}

\author{
Faisal M. Almutairi ${ }^{1}$, Abdullah A. Almodaires ${ }^{1}$ \& Alaa J. Zeyab ${ }^{1}$ \\ ${ }^{1}$ College of Basic Education, Department of Educational Technology, The Public Authority for Applied \\ Education and Training (PAAET), Kuwait \\ Correspondence: Faisal M. Almutairi, College of Basic Education, Department of Educational Technology, The \\ Public Authority for Applied Education and Training (PAAET), Kuwait.
}

\begin{tabular}{|c|c|c|}
\hline Received: November 9, 2019 & Accepted: February 1, 2020 & Online Published: June 25, 2020 \\
\hline doi:10.5539/ies.v13n7p163 & URL: https://doi & $10.5539 /$ ies.v13n7p163 \\
\hline
\end{tabular}

\begin{abstract}
In the current study, the aim is to determine the effectiveness of flipped learning approach in developing pre-service teachers' skills and knowledge in creating and editing digital videos. Furthermore, the approach was evaluated through the theoretical lens of constructivism and experiential learning.

This research was conducted within a workshop course for six weeks period during the summer semester of the 2018-2019 academic year at a teacher training college in Kuwait. In the study, pre-test/post-test quasi-experimental design with control group was applied. The experiment involved applying a flipped learning approach to the experimental group while the courses were carried out using traditional lectures in the control group. A questionnaire was also administered to the experimental group to acquire feedback on the effectiveness of flipped learning activity. Descriptive statistics, Mann Whitney U Test and Wilcoxon Sign Test were used in the analysis of the quantitative data.

The results obtained from Mann Whitney U Test and Wilcoxon Sign Test suggests that there is no significant difference between the pre-test and post-test scores of the experimental group and the control group. Descriptive data also demonstrated that the use of the flipped learning method in the curriculum had significantly increased the skill levels and knowledge of the experimental group pre-service teachers. The study recommends that care should be taken when structuring courses in pre-service teachers' education when applying flipped learning.
\end{abstract}

Keywords: flipped learning, pre-service teacher education, quasi-experimental, digital video

\section{Introduction}

Flipped learning, which is supported by constructivist learning theory, is usually considered to be a change in the use of in- and out-of-class time, for instance, the use of technology for in-class activities that emphasize active learning and collaborative learning, and out of class time for watching online lectures or independently exploring content (Abeysekera \& Dawson, 2015; McLaughlin et al., 2014; Roehl, Reddy, \& Shannon, 2013). This involves online delivery of content by teachers and student engagement with the content. However, if students are to actively engage with the content, manipulate the knowledge and apply it to a variety of situations and contexts, then the flipped learning approach has to be structured (Yough et al., 2017). It provides opportunities for experiential learning and therefore can be used in informal and outdoor education settings (Tomas, Evans, Doyle, \& Skamp, 2019). Although flipped learning has received considerable attention in recent years, very little is known about its effect on skills and knowledge attainment or learning outcomes of preservice teachers (Yough et al., 2017; Ng, 2016; Bishop \& Verleger, 2013) The purpose of the present study was to address this gap. An examination of flipped learning in pre-service teacher education was considered important as they may proceed to adopt the practices to which they are exposed, influencing the next generation of students, teachers, administrators, and policy makers

\section{Literature Review}

This literature review examines research related to the influence of the flipped learning approach on pre-service teacher learning as well as skill and knowledge attainment in the video production process. The key themes that have emerged from this literature review address issues pertaining to: the novelty of flipped learning approach (Bishop \& Verleger, 2013; effectiveness of flipped learning (Cronhjort, Filipsson, \& Weurlander 2017; Kwon \& 
Woo, 2018), empowering pre-service teachers (Almodaires, Alayyar, Almsaud, \& Almutairi, 2019; Fraga \& Harmon, 2014), improved learning outcomes or student achievement (Jeong, Cañada-Cañada, \& González-Gómez, 2018), enhanced skill levels, knowledge and richer understanding of concepts/topics (Yough et al., 2017; Lee \& Lai, 2017; Hattie \& Donoghue, 2016; McLaughlin et al., 2014).

\subsection{Flipped Learning}

Flipped learning represents 'Flexible environments', 'Learning culture', 'Intentional content', and 'Professional educators' (FLIP) (Chen, Wang, Kinshuk, \& Chen, 2014). Flipped learning is a fairly new approach and has been defined as one that employs "interactive group learning activities inside the classroom, and direct computer-based individual instruction [i.e., video lectures] outside the classroom" (Bishop \& Verleger, 2013, p. 5). It is an interactive pedagogical model in which the information and content instruction takes place outside of class time, and class time is instead used for interactions and conceptual development (Cronhjort, Filipsson, \& Weurlander, 2017; Kwon \& Woo, 2018). In-class time is used for cooperative learning and involves discussions or interactive activities that promote critical thinking, teamwork, personalised learning, and content knowledge acquisition (García-Sánchez \& Santos-Espino, 2017). The flipped learning approach allows students to take responsibility for their learning process since they must spend time watching a video presentation, listening to online content (for example podcast) or reading (for example e-books, journals) at a suitable time and place outside of the classroom (Almodaires et al., 2019; Anderson, Young, \& Franklin, 2014). Therefore, it is claimed to be a ubiquitous learning method that provides constant opportunity for out of class learning supported by technology (García-Sánchez \& Santos-Espino, 2017).

According to McLaughlin et al. (2014) one of the benefits of flipped learning is associated with the development of generic skills, for example collaboration, communication, creativity, critical thinking, information technology and digital competence, numeracy, problem-solving and self-management. Research evidence suggests that flipped learning not only stimulates higher level of thinking, problem-solving skills and self-directed learning skills, but enhances lifelong learning skills and prepares students to learn and adapt the skills once they join the working world (Lee \& Lai, 2017; Hattie \& Donoghue, 2016; Rateau, Kaufman, \& Cletzer, 2015). Besides, the interactive nature of the learning approach enables team work and interactions with lecturers or peers (Nwosisi, Ferreira, Rosenberg, \& Walsh, 2016).

Face-to-face in-class activities create dynamic, interactive learning environments "where the educator guides students as they apply concepts and engage creatively in the subject matter" (Flipped Learning Network, 2014, p. 1). Therefore, it is claimed that flipped learning can develop students' communication and collaboration skills (McLaughlin et al., 2014; Kwon \& Woo, 2018). Ng (2016) examined the photo editing skills (a generic skill) of pre-service teachers in a flipped classroom and found that the approach allowed the students to apply the self-learnt subject knowledge to a real situation. On the contrary, research also demonstrates that flipped learning does not have an effect on changes in students' knowledge or skills (Chen, Liu, \& Martinelli, 2017).

Ayçiçek and Yanpar-Yelken (2018) investigated the effect of flipped classroom model on students' classroom engagement in teaching English and used a pretest/post-test quasi-experimental design. The study found that there was no significant difference between the experimental group that was taught using the flipped learning approach and the control group that was taught using traditional lectures. The results of Ayçiçek and Yanpar-Yelken's study were validated by Cabi (2018) who also found that there were no statistically significant differences between the scores of the experimental group (flipped learning) and the control group. Nevertheless, there is sufficient evidence to suggest that flipped learning allows more time for one-to-one instruction in the classroom (McCallum et al., 2015; Hamdan et al., 2014). Lai, Lin, and Yueh (2020) explored the effectiveness of flipped learning classes on students' learning achievement and motivation and found that students in the flipped classes (experimental group) performed better than those in the control group. In other words, there was a significant difference in students' knowledge between the two groups. These findings suggest that the approach can improve learning by engaging "students in meaningful sense-making activities on difficult content" (Talbert, $2014 \mathrm{p}$. $365)$.

\subsection{Flipped Learning and Development of Pre-Service Teachers' Educational Attainment}

Vaughan (2014) asserts that flipped learning can play an important role in pre-service teacher education as the approach promotes active-learning strategies and peer collaboration. This approach provides pre-service teachers understand how to make pedagogical choices and decisions connected to their teaching objectives as well as to observe how technology can be integrated in classrooms. Jeong et al. (2018) assessed pre-service teachers' performance, perceptions, and emotions in a flipped-classroom setting in science education and found that the student-teachers were able to participate and engage more successfully in their class and attain better learning 
outcomes. Moreover, the findings suggest that the flipped learning approach promoted more student interaction and participation than traditional teaching format. These results indicate that social dimension is an important aspect of interactive classrooms (Naccarato \& Karakok, 2015; Weurlander et al., 2016). There is sufficient evidence that students perform better in active learning flipped classrooms compared to traditional lectures (Almodaires et al., 2019; Cronhjort, Filipsson, \& Weurlander, 2017).

Jungic et al. (2015) found that students who watched video lectures were well prepared for class and believed that they could learn at their own pace. Similar findings have also been reported by other authors (Cronhjort \& Weurlander, 2016; Love et al., 2014). In another study, Yoshida (2016) found that flipped classrooms enhanced classroom instruction, improved learning effectiveness, enhanced productivity and fostered self-paced learning. Student in the study reported that flipped classrooms were effective because the approach allowed students to view video lectures multiple times, increase understanding of the course and for enhance self-regulated learning.

Cronhjort, Filipsson, and Weurlander (2017) examined the effect of replacing traditional lecture-based teaching in calculus with a flipped learning approach and used a pre-test and post-test as well as a survey to measure student engagement and student learning achievement. They concluded that the students who were exposed to the flipped learning approach performed much better. Similar results were reported by Fraga and Harmon (2014) who found that pre-service teachers in the flipped classroom were more confident, better prepared to utilise teaching strategies, and a greater willingness to discuss ideas in class than the traditional group. With regard to learning outcomes there were no differences in exam scores across groups.

García-Sánchez and Santos-Espino (2017) investigated the educational outcomes of pre-service instructors as they produced foreign language educational videos over a two-year period in a ubiquitous learning environment. Results of the study, in which pre-service teachers effectively linked digital technology with pedagogy, revealed that the teachers were able to successfully combine instructional dynamics with digital skills and knowledge to produce flipped classes adapted to the needs of young learners.

However, studies have found that not all students prefer flipped classes as they are used to lectures and believe that they do not have access to an expert while viewing the videos outside the classroom (for example Chen et al. 2014; Engin, 2014). Researchers claim that students preferred more traditional classrooms as those approaches are more consistent with students' previous formal educational experiences and in line with their conception of teaching (Levin, 2015; Cobb, 2016). Therefore, students would be less likely to take a flipped class. This evidence suggests that the outcomes of studies that compare the effectiveness of flipped learning with traditional lectures are mixed.

In sum, the scope of the studies reviewed in this literature review was limited to the effectiveness of flipped learning in fostering pre-service teachers' skills or competencies and educational attainment.

\subsection{Theoretical Framework}

The two theories underpinning this study are Kolb's experiential learning and constructivism (Table 1). Flipped Learning is a relatively new instruction methodology which has its foundations in constructivism. This approach is congruent with constructivist learning theory as it is associated with differentiated instruction, active learning, student-centred collaborative learning, group discussions, promoting teacher-student interactions and problem solving (Gilboy, Heinerichs, \& Pazzaglia, 2015; Lumpkin, Achen, \& Dodd, 2015; Fraga \& Harmon, 2014; Larcara, 2014).

The flipped learning approach also draws on the experiential learning concept which is synonymous with active learning and defined as "making meaning from direct experience" and "learning through reflection on doing" which can occur with or without a facilitator, or "teacher" (Patrick, 2011; Wurdinger \& Carlson, 2010). According to Kolb (2014) learning is the process whereby knowledge is created through the "transformation of experience" in a specific learning environment (p. 38). Kolb's theory posits that students are transformed by their learning and will be able to apply the skills acquired directly in the workplace (Kolb, 1984), for example a classroom. 
Table 1. Underpinning theories

\begin{tabular}{lll}
\hline Experiential Learning & Constructivism \\
\hline - $\quad$ Learners experiencing real-world experiences on their own. & Learners constructing knowledge or developing own \\
Learners viewing the experience from multiple perspectives & $\begin{array}{l}\text { understanding through dialogic discourse or interactive } \\
\text { discussions (social interaction) with teachers and peers } \\
\text { (teachers, peers) and forming abstract concepts. }\end{array}$ - $\begin{array}{l}\text { Learners engaging in activities that promote } \\
\text { Learners watching others and reflecting upon what they have }\end{array}$ & $\begin{array}{l}\text { student-centred learning, active learning, cooperative } \\
\text { learned. }\end{array}$ \\
$\begin{array}{l}\text { Learners integrating the new experience into practice through } \\
\text { decision making and by finding solutions to immediate problems } \\
\text { for a forthcoming experience (in the classrooms as future teachers) }\end{array}$ & $\begin{array}{l}\text { Teachers encouraging learners to be responsible and } \\
\text { autonomous }\end{array}$ \\
\hline
\end{tabular}

(Source: Gilboy et al., 2015; Lumpkin et al., 2015; Fraga \& Harmon, 2014; Larcara, 2014).

The framework (Figure 1) shows that when engaged in in-class activities, flipped learning will allow for a learner-centric, facilitative, socially constructivist approach as pre-service teachers work together to find solutions (Roehl et al., 2013). On the other hand, when engaged in pre-class activities (outside the classroom) the pre-service teachers work independently (Tomas et al. 2019).

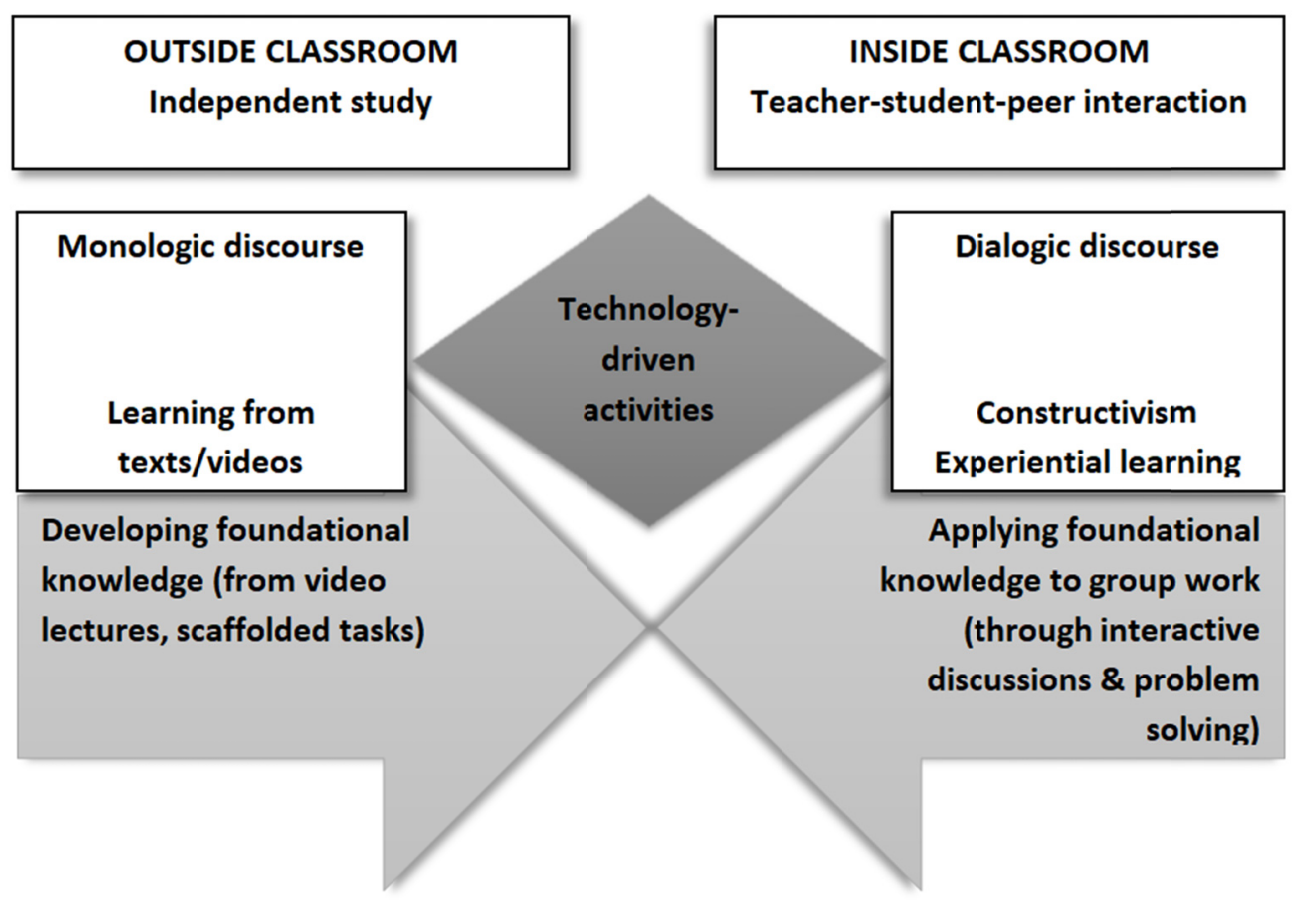

Figure 1. Theoretical framework (adapted from Tomas et al., 2019 and Wood et al., 2018)

Monologic discourse is usually associated with fixed transmission of static ideas (Wood et al. 2018). In the framework, monologic discourse refers to learning through observations of video lectures and reading books. Dialogic discourse, or teacher-student interactions, signifies social relationships, intellectual openness, and opportunities for analysis and creative thought (Wood et al. 2018). Dialogic discourse refers to applying foundational knowledge to group work through interactive whole class discussions and problem solving. Therefore, flipped learning is characterised by dialogic and monologic discourse, high levels of student autonomy, higher order thinking and opportunities to apply and extend knowledge through problem-solving (Tomas et al. 2019).

The framework reconceptualises Kolb's philosophy and illustrates that flipped learning is experiential learning from a constructivist perspective. The two theories presented here were used to interpret the results of the study. 


\section{Aim, Research Questions and Research Hypotheses}

The aim of the present study was to determine the effectiveness of flipped learning approach by comparing pre-service teachers' knowledge and skills between a flipped classroom implementation and traditional teaching of a video production course. In other words, the objective of this study was to investigate whether flipped classrooms result in increased skill and knowledge attainment (learning outcomes) in a teacher education programme. To this end, the problem statements of the study were worded as follows:

Research question 1: Is there a significant difference between the skill and knowledge levels of student-teachers taught with flipped learning and that of student-teachers taught by the face-to-face teaching method?

The sub-problems of the study are:

a) "Is there a significant difference between the pre-test scores of the pre-service teachers in the experiment group (EG) taught by the Flipped Learning method using demonstration videos, and the pre-service teachers in the control group (CG) taught only on the basis of the instructional materials to generate digital video (so that they develop video making skills and knowledge)?"

$\mathrm{H}_{0} 1$ There is no statistically significant difference in the pre-test scores of the pre-service teachers in EG and CG before using the Flipped Learning method.

$H_{A} 1$ There is a statistically significant difference in the pre-test scores of the pre-service teachers in EG and CG before using the Flipped Learning method.

b) "Is there a significant difference between the post-test scores of the pre-service teachers in the EG taught by the Flipped Learning method using demonstration videos, and the pre-service teachers in the CG taught only on the basis of the instructional materials to generate digital video (so that they develop video making skills and knowledge)?"

$\mathrm{H}_{0} 2$ There is no statistically significant difference in the post-test scores of the pre-service teachers in EG and CG after using the Flipped Learning method.

$\mathrm{H}_{\mathrm{A}} 2$ There is a statistically significant difference in the post-test scores of the pre-service teachers in EG and CG after using the Flipped Learning method.

c) Is there a significant difference between the pre-test and post-test scores of the pre-service teachers in the EG taught by the Flipped Learning method?

$\mathrm{H}_{0} 3$ There is no statistically significant difference between the pre-test and post-test scores of the pre-service teachers in the $E G$.

$\mathrm{H}_{\mathrm{A}} 3$ There is a statistically significant difference between the pre-test and post-test scores of the pre-service teachers in the $E G$.

d) Is there a significant difference between the pre-test and post-test scores of the pre-service teachers in the CG taught by the non- Flipped Learning method?

$\mathrm{H}_{0} 4$ There is no statistically significant difference between the pre-test and post-test scores of the pre-service teachers in the $C G$.

$\mathrm{H}_{\mathrm{A}} 4$ There is a statistically significant difference between the pre-test and post-test scores of the pre-service teachers in the $C G$.

Research question 2: How do pre-service teachers in the EG perceive the use of the flipped learning approach in terms of its usefulness for skill and knowledge attainment in producing videos?

\section{Research Design and Methods}

This research focuses on an experiment that was carried out during the academic year 2018-2019 at PAAET's College of Basic Education. The College of Basic Education is one of only two Kuwaiti colleges that offers teacher education programmes in Kuwait (Almodaires et al., 2019). The focus of this study is the Department of Educational Technology at the College of Basic Education where pre-service teachers were taught workshop classes focusing on how to generate digital videos.

This study employed a quasi-experimental design to assess the effect of using flipped teaching method on preservice teachers' learning outcome as well as skill and knowledge attainment when producing and editing videos. The rationale for using a quasi-experimental design was to estimate the causal impact of an intervention on its target population (to test a causal hypotheses), without random assignment to either the EG or CG (White $\&$ Sabarwal, 2014). The study has one independent variable: the teaching method (lecture-based or flipped-based 
method) and two dependent variables: (1) learning outcomes (2) students' feedback on the effectiveness of flipped learning to create videos.

\subsection{Methods}

The research questions and methods used are tabulated below.

Table 2. Research questions and methods used

\begin{tabular}{lll}
\hline Research Question & Methods \\
\hline $1 \quad \begin{array}{l}\text { Is there a significant difference between the skill and knowledge levels of student-teachers taught with } \\
\text { flipped learning and that of student-teachers taught by the face-to-face teaching method? }\end{array}$ & $\begin{array}{l}\text { Mann Whitney U Test and } \\
\text { Wilcoxon Sign Test }\end{array}$ \\
2 & $\begin{array}{l}\text { How do pre-service teachers in the EG perceive the use of the flipped learning approach in terms of its } \\
\text { usefulness for producing videos? }\end{array}$ & $\begin{array}{l}\text { Questionnaire - Descriptive } \\
\text { statistics }\end{array}$ \\
\hline
\end{tabular}

The methods used in this study included conducting an experiment to find out the effectiveness of flipped learning approach and administering questionnaires to obtain students' feedback of their flipped learning experiences.

\subsection{Sampling}

A combination of purposeful and convenience sampling, which are non-probability sampling techniques, were used to select the pre-service teachers. This procedure enabled identifying participants who would receive the treatment (EG), and those who would be taught using traditional lectures (CG). Participants were recruited through direct communication between the instructors and students in the class. The participants were 78 pre-service teachers (37 EG; $41 \mathrm{CG}$ ), enrolled in technology integration courses at the College of Basic Education.

\subsection{Ethical Considerations}

Informed consent was obtained from the pre-service teachers after participant information sheets highlighting the importance of the research were distributed to the students. The pre-service teachers were informed about the research, most specifically about the nature of the research, instruments and the way the data would be analysed.

The pre-service teachers were informed that their participation was voluntary and that they had the freedom to withdraw at any time from the study. To protect participants' interests, their identity was protected by using pseudonyms. In other words, participants were assured of anonymity. The participants were also informed that the data collected from them would be kept confidential. Incentives were not provided to students for participating in this experiment.

\subsection{Procedures for the Experiment}

The workshop course selected for the experiment was taught by the same instructor in two different classrooms. The students from these classrooms were required to attend two 3-hours classes weekly in the summer semester. The instructor used demonstration videos to clarify important technical skills that student need for video production process, for instance production scale, shooting style and techniques, camera movement and post-production editing.

All learning materials used in the flipped teaching method, including videos, course content, pre-test and post-test quiz as well as feedback questionnaire were released to the respective student groups. For six weeks, the students in the experimental group were taught in a blended learning context where the flipped learning model was applied. The flipped teaching strategy, involved student-teachers watching demonstration videos and reading the chapter or online materials before class (at home). Class time was dedicated for hands-on activities. The student-teachers worked through activities guided by the instructor and the support of their peers. These activities contained a large collaborative element for the instructional component which allowed the student-teachers to ask questions to instructor and their peers. The control group were taught using traditional blended learning which was based on lectures and direct teachings conducted by the instructor, while students listened to lectures and learnt from them. In this method, students learnt through the assignments completed at home. The activities performed before, during and after class by the two groups are tabulated below. 
Table 3. Activities of EG and CG - Before, during and after class

\begin{tabular}{lll}
\hline Time & Control Group (CG) & Experimental Group (EG) \\
\hline Before class & & Watching demonstration videos/Reading online course content \\
During class & Lectures and direct teaching & Group discussion and hands-on activities related to the course materials \\
After class & Homework & \\
\hline
\end{tabular}

Both groups were administered summative tests before and after the flipped classroom sessions. The pre-test, comprising of 10 multiple-choice items, was tailored to assess pre-service teachers' ability to understand technical terms associated with creating videos. The post-test, also comprising of 10 items was meant to elicit participants' retention and transfer of knowledge of these topics. Examples of some of the questions include:

i. Tilting the camera sideways so that vertical lines run diagonally is known as: operator error/slant shot/tilt shot/Dutch tilt

ii. The smallest unit in a movie is: Shot/scene/sequence

iii. A group of camera shots that are connected in time and place is: Shot-list/scene/sequence

iv. The most used camera shot for an interview is known as: Direct shot/interview shot/over shoulder shot/wide shot

v. What shot is a distance away from a subject? Close up/ Medium shot/ Long shot/ None of the above

vi. Moving the camera head in vertical direction is called: Tilting/panning/tracking/arching

vii. Tick all those techniques a video editor should know: Use standard cut to connect frames together in a simple, straightforward flow; Master the Montage; Cutaway Shots; Match Cuts; Short cuts.

viii. Tick all those skills a video editor should have: a good sense of timing; visual awareness; practical and creative skills; attention to detail; patience and concentration; IT skills; communication skills.

ix. The "rule of thirds" is essential for composing visual image in photography only: True /false

x. $\quad$ Tick only those software that can be used for video editing: CyberLink PowerDirector; Adobe Premiere Elements; Adobe Photoshop; Pinnacle Studio; Purple Studio; Adobe Premiere Pro; Windows Movie Maker; Apple Final Cut Pro X; HitFilm Pro; Pineapple cut.

\section{Results and Interpretation}

\subsection{Post-Test/Pre-Test}

In order to resolve the research problems, the pre-test and post-test scores of the student-teachers in the experimental and control groups were compared using the Mann Whitney U Test and Wilcoxon signed rank tests. Normally, parametric statistical tests (such as a T-tests and One-Way ANOVA) are used when a researcher makes assumptions about the parameters of a population from which the data is drawn. The rationale for using nonparametric tests (for example Mann Whitney U Test and Wilcoxon signed rank tests) was because the sample size was small and the data did not meet the assumptions of the parametric test (Conover, 1999). Mann-Whitney U test was deployed to detect differences in the improvements made by pre-service teachers in the experimental and control groups when editing and creating digital videos. Wilcoxon signed rank test was applied to examine changes in learning outcomes (skills and knowledge) within each group separately, before and after the application of the flipped learning approach. Furthermore, the Wilcoxon signed rank test was used to examine changes in learning within each group. Regarding the significance level, the value of .05 , which is most frequently used in educational studies, was considered.

\subsubsection{Mann Whitney U Test}

In order to test the hypotheses $\left(\mathrm{H}_{0} 1\right.$ and $\left.\mathrm{H}_{0} 2\right)$ of this study, the pre-test and post-test scores of the pre-service teachers in the experimental and control groups were compared using the Mann Whitney $\mathrm{U}$ test, a non-parametric statistical technique. 
Table 4. Results of the Mann Whitney U test to compare the groups' pre-test scores

\begin{tabular}{ccccccc}
\hline Groups & $\mathrm{N}$ & Rank Average & Sum of Ranks & U-value & Z-value & p-value \\
\hline $\begin{array}{c}\text { Experimental } \\
\text { Group }\end{array}$ & 37 & 43.23 & 1599.5 & & & \\
Control Group & 41 & 36.13 & 1481.5 & & & \\
\hline
\end{tabular}

An examination of the findings in Table 4 reveals the results of Mann Whitney $U$ test for the pre-test scores of the pre-service teachers in the experimental and control groups did not show any statistical difference $(\mathrm{U}=620.5$; $\mathrm{p}=.168>.05)$. Here, the calculated $p$-value exceeds .05 , meaning that the data falls within the range of what would happen $95 \%$ of the time. The rank average of the pre-test scores of the experimental group students was 43.23, while the students in the control group had a pre-test score rank average of 36.13 . The rank averages of the groups' pre-test scores were not close and suggest that before the experimental application of the flipped learning approach, the experimental and control groups did not have equal pre-test skill and knowledge levels in using software/hardware for creating and editing digital video. The result is that the $\mathrm{p}$-value $(p=.168)$ which is greater than 0.05 and the null hypothesis $\left(\mathrm{H}_{0} 1\right.$ - there is no statistically significant difference in the pre-test scores of the pre-service teachers in EG and CG) and was not rejected. Therefore, it cannot be concluded that a significant difference exists.

Table 5. Results of the Mann Whitney U test to compare the groups' post-test scores

\begin{tabular}{ccccccc}
\hline Groups & $\mathrm{N}$ & Rank Average & Sum of Ranks & U-value & Z-value & p-value \\
\hline Experimental Group & 37 & 41.74 & 1544.5 & \multirow{2}{*}{675.5} & -0.8255 & \multirow{2}{*}{407} \\
Control Group & 41 & 37.48 & 1536.5 & & \\
\hline
\end{tabular}

An examination of the findings in Table 5 shows that the results of the Mann Whitney U test applied to the post-test scores of the pre-service teachers in the experimental and control groups did not show any statistical difference $(\mathrm{U}=675.5 ; \mathrm{p}=.407>.05)$. The rank average of the post-test scores of the experimental group pre-service teachers was 41.74, while the pre-service teachers in the control group had a post-test score rank average of 37.48. Overall, the analyses had shown no significant difference between the rank averages of the groups' pre-test and post-test scores. The result is that the $\mathrm{p}$-value $(p=.407)$ is greater than 0.05 and the null hypothesis $\left(\mathrm{H}_{0} 2\right.$ - that there is no statistically significant difference in the post-test scores of the pre-service teachers in EG and CG) was not rejected. Therefore, it cannot be concluded that a significant difference exists.

\subsubsection{Wilcoxon Signed-Ranks Test}

In order to test the hypotheses $\left(\mathrm{H}_{0} 3\right.$ and $\left.\mathrm{H}_{0} 4\right)$ of this study, the pre-test and post-test scores of the pre-service teachers were examined using the Wilcoxon Signed-Ranks Test to see if there were changes in learning outcomes within the same group.

Table 6. Results of the Wilcoxon Signed-Ranks test to compare the pre-test-post-test academic achievement scores of the students in the experimental group

\begin{tabular}{ccccc}
\hline Groups & $\mathrm{N}$ & $\mathrm{W}$-value & Z-value & $\mathrm{p}$-value \\
\hline Experimental Group & 37 & 5 & 5.153 & .00001 \\
Control Group & 41 & 5 & & \\
\hline
\end{tabular}

As an examination of the findings in Table 6 shows there is a significant difference between the pre-test and post-test scores of the pre-service teachers in the experimental group $(\mathrm{Z}=5.153, \mathrm{p}=.00001<.05)$. Since the $\mathrm{p}$-value $(p=00001)$ is less than 0.05 , the null hypothesis $\left(\mathrm{H}_{0} 3\right)$ that there was no statistical difference between the pre-test and post-test scores was rejected. Therefore, it was concluded that a significant difference does exist. 
Table 7. Results of the Wilcoxon Signed-Ranks test to compare the pre-test-post-test academic achievement scores of the students in the control group

\begin{tabular}{ccccc}
\hline Groups & $\mathrm{N}$ & $\mathrm{W}$-value & Z-value & $\mathrm{p}$-value \\
\hline Experimental Group & 37 & 28.5 & -5.2093 & .00001 \\
Control Group & 41 & & & \\
\hline
\end{tabular}

When the $\mathrm{z}$ values in Table 7 are examined it can be seen that there is a significant difference between the pre-test and post-test scores of the pre-service teachers in the control group $(Z=-5.2093, p=.00001<.05)$. Since the $p$-value $(p=00001)$ is less than 0.05 , the null hypothesis $\left(\mathrm{H}_{0} 4\right)$ that there was no statistical difference between the pre-test and post-test scores was rejected. Therefore, it was concluded that a significant difference does exist.

This would also indicate that although the use of the non-flipped approach appeared to have helped enhance the skills and knowledge of the students in the $\mathrm{CG}$, the pre-service teachers in the group failed to reach the skill and knowledge levels demonstrated by the EG, who were taught using a flipped classroom approach.

\subsection{Questionnaire: Feedback on the Effectiveness of the Flipped Learning Activity}

To address the $2^{\text {nd }}$ research question, a questionnaire was distributed to the pre-service teachers with the purpose of acquiring feedback on the effectiveness of the flipped learning activity in attaining video producing/editing skills. The questionnaire (see Appendix A) was adapted and modified from a validated questionnaire developed by Pierce and Fox (2012) and revalidated by Barua, Gubbiyappa, Baloch, and Das (2014). The instrument was revalidated by testing the scales. Gall et al. (2015) considered a value of .70 or higher usually as adequate but the reliability (Cronbach's alpha) of the research instrument was found to be 0.912 . The questionnaire consisted of items arranged according to a five-point Likert scale, ranging from 'Strongly disagree' to 'Strongly agree'.

Descriptive statistics (means, standard deviation) were used to analyse the questionnaire data (see Table 8). The total questionnaire response rate was $100 \%(\mathrm{n}=128)$. After accounting for respondents who returned incomplete questionnaires for some items (e.g., Questions 3, 5, 6, 7, 8, \& 9), the adjusted response rate was 30.56\% $(n=99.22)$.

Table 8. Descriptive statistics

\begin{tabular}{|c|c|c|c|c|c|c|}
\hline Questionnaire Items & $\mathrm{N}$ & Min & Max & $\mathrm{M}$ & SD & $\begin{array}{l}\% \text { Agreement } \\
(\mathrm{A}+\mathrm{SA})\end{array}$ \\
\hline $\begin{array}{l}\text { Q1. The videos and lessons were available on e-learning portal before the } \\
\text { Flipped Learning activity }\end{array}$ & 37 & 4 & 5 & 4.73 & 0.450 & $100 \%$ \\
\hline $\begin{array}{l}\text { Q2. I had adequate time to view the videos and lessons before the Flipped } \\
\text { Learning activity }\end{array}$ & 37 & 3 & 5 & 4.62 & 0.639 & $92 \%$ \\
\hline Q3. The videos and lessons were relevant for the Flipped Learning activity & 37 & 3 & 5 & 4.84 & 0.442 & $97 \%$ \\
\hline $\begin{array}{l}\text { Q4. The classroom arrangements were appropriate for the Flipped Learning } \\
\text { activity }\end{array}$ & 37 & 2 & 5 & 4.27 & 0.838 & $86 \%$ \\
\hline $\begin{array}{l}\text { Q5. The activities during Flipped Classroom session improved my } \\
\text { understanding of the key concepts }\end{array}$ & 37 & 3 & 5 & 4.62 & 0.545 & $97 \%$ \\
\hline $\begin{array}{l}\text { Q6. The Flipped Classroom session inspired me to pursue further learning for } \\
\text { the module }\end{array}$ & 37 & 1 & 5 & 4.03 & 1.142 & $68 \%$ \\
\hline Q7. More lectures should be conducted in the Flipped Classroom mode. & 37 & 2 & 5 & 3.89 & 1.100 & $68 \%$ \\
\hline Q8. The lecturer was able to engage me in the Flipped Learning activity & 37 & 2 & 5 & 4.54 & 0.767 & $89 \%$ \\
\hline $\begin{array}{l}\text { Q9. The lecturer was able to provide clarification on difficult concepts during } \\
\text { the Flipped Learning activity }\end{array}$ & 37 & 3 & 5 & 4.62 & 0.545 & $97 \%$ \\
\hline $\begin{array}{l}\text { Q10. The lecturer was able to expand on online videos and lessons during the } \\
\text { Flipped Learning activity }\end{array}$ & 37 & 2 & 5 & 4.41 & 0.798 & $86 \%$ \\
\hline
\end{tabular}

The results revealed that most of the respondents were content with the Flipped Learning setting, with $100 \%$ of the pre-service teachers 'agreeing' that the videos and lessons were available on the e-learning portal before the Flipped Learning activity (Q1); and over $90 \%$ of the participants 'agreeing' with four items (Q2, Q3, Q5, Q9) in the feedback questionnaire. These include adequate time to view the videos and lessons before the Flipped Learning activity, the videos and lessons were relevant to the Flipped Learning activity, activities improved their understanding of the key concepts, and the lecturer was able to provide clarification on difficult concepts. 
Likewise, over $80 \%$ of the pre-service teachers 'agreed' that the classroom arrangements (positioning of the chairs for group activity, availability of cameras, computers and editing software etc.) were appropriate for the activity (Q4), the lecturer engaged them (Q8), and that the lecturer was able to expand on the video production process during the activity (Q10). However, there was no unanimous agreement to the questions on whether the pre-service teachers were really inspired that the activity would enable them to further learn about the course (68\%), and whether more lectures should be conducted in the Flipped Learning mode (68\%). Overall, most participants provided quality feedback on the Flipped Learning activity.

\section{Key Findings and Discussion}

The results of the Mann-Whitney U test and Wilcoxon Signed Rank test and the results of the questionnaire were triangulated and findings are presented below.

\subsection{Hypothesis $H_{0} 1$ and $H_{0} 2$}

The groups' pre-test scores were compared using the Mann Whitney U test and from the results it cannot be concluded that a significant difference exists between the skills, knowledge and learning outcomes of the pre-service teachers in the EG and CG before and after flipped leaning was applied. In other words, for $\mathrm{H}_{0} 1$ it cannot be concluded that a significant difference exists.

Likewise, the post-test scores of the pre-service teachers in the experimental and control groups did not show any statistical difference. Therefore, for $\mathrm{H}_{0} 2$ it cannot be concluded that a significant difference does exist. On the other hand, the results of related studies in the relevant literature reflect that the flipped learning method increases students' skill levels and knowledge (Jeong et al., 2018; Yough et al., 2017; Lee \& Lai, 2017; Hattie \& Donoghue, 2016).

\subsection{Hypothesis $H_{0} 3$ and $H_{0} 4$}

On the basis of the results of the pre-test and post-test scores of each individual group obtained from the Wilcoxon Signed-Ranks Test, it could be argued that the use of the flipped learning method in the curriculum had significantly increased the skill levels and knowledge of the experimental group pre-service teachers. Although, the digital video editing and creation lectures had also increased the skill and knowledge levels of the pre-service teachers in the control group, it was not to the level of the EG. Based on the results, for $\mathrm{H}_{0} 3$ and $\mathrm{H}_{0} 4$, it was concluded that a significant difference does exist. This finding corroborates the results previous studies that had used pretest/post-test quasi-experimental designs (for example Lai, Lin, \& Yueh, 2020; Ayçiçek \& Yanpar-Yelken, 2018; Cabi, 2018) that also concluded that there is a significant difference between the pre-test and post-test scores of the experimental group taught using the flipped learning approach as compared to the control group.

\subsection{Questionnaire}

An analysis of the descriptive statistics revealed that the pre-service teachers in the EG were satisfied with the flipped learning approach and provided quality feedback on the learning activities.

In the current study, it was observed that there was no significant difference between the experimental and control groups according to pre-test and post-test results in pre-service teachers' skills and knowledge in producing videos. This finding seems to support the claims of Chen, Liu and Martinelli (2017) that although this pedagogical approach could lead to improved student motivation and engagement, it may not have an effect on changes in students' knowledge and skills. It also refutes the results of previous studies that students perform better in flipped classrooms compared to traditional lectures (Almodaires, Alayyar, Almsaud, \& Almutairi, 2019; Cronhjort, Filipsson, \& Weurlander, 2017). However, the findings uphold results reported by Fraga and Harmon (2014) that the application of flipped learning would have a significant effect on the experimental group.

Based on an analysis of the descriptive data, the flipped learning approach appeared to have facilitated constructivist and experiential learning. The very nature of video creation and its focus on documenting and reflecting on progress had supported pedagogy of experiential learning. The flipped learning methods provided them with an opportunity to clarify difficult concepts through interaction in class, which created pathways for exploration and discovery, thus supporting the pedagogical paradigm of social constructivism. It has been well documented in the literature that interaction facilitates learning (Bishop \& Verleger, 2013; Cronhjort, Filipsson, \& Weurlander 2017; Kwon \& Woo, 2018; Naccarato \& Karakok, 2015). These results suggest that the flipped learning approach can help develop a range of skills and knowledge to master the basics of video production.

Another finding was that many pre-service teachers were averse to flipped learning. This may be due to the fact that in the flipped learning model, pre-service teachers were not inspired by the activities and were more used to 
traditional lectures. This finding is consistent with the results of previous studies (for example Chen et al., 2014; Engin, 2014) that found that students prefer traditional lectures as they feel a lecturer can connect and draw them into the lecture. Therefore it is suggested that educators should not expect that a move to a flipped learning method would spontaneously inspire students (Levin, 2015; Cobb, 2016).

In sum, these findings lend general support to the notion that flipped classrooms better prepare pre-service teachers for careers in education (Vaughan, 2014). Findings corroborate results a previous study conducted in Kuwait (Almodaires et al., 2019) and confirm that flipped learning may be a promising approach to enhance pre-service teachers' learning. The results of this study suggest that the introduction of flopped learning in pre-service teacher education is necessary and a step in the right direction as it would enable these teachers of the future to successfully combine pedagogical dynamics with video making skills and knowledge to produce flipped classes adapted to the needs of young learners (García-Sánchez \& Santos-Espino, 2017).

\section{Limitations}

The use of a purposive sample, a non-probability sampling method, for administering the questionnaire is one of the limitations of this study. Only participants who were thought to be relevant to the research were purposively chosen. Therefore, it can result in a biased sample and the results cannot be generalised to the entire population. Unlike in probability sampling (for example random sampling), the participants in the population did not have nonzero probabilities of selection. Rather, subjective methods were used to decide which participant should be included in the sample. Therefore, the findings were not interpreted beyond the sampled population. In future studies, if this technique were to be used, the sample size would be increased to reduce the effect of over-dependence on available participants and thereby ensuring a realistically representative sample (Sarantakos, 2013).

\section{Conclusions, Future Reflections and Recommendations}

This article has aimed to shed some light on the application and effectiveness of flipped learning for pre-service teachers at a teacher training college in Kuwait.

Although there was no statistically significant difference in the pre-test $\left(\mathrm{H}_{0} 1\right)$ and post-test $\left(\mathrm{H}_{0} 2\right)$ scores of the pre-service teachers in EG and CG, the results of the application of the flipped classrooms for examining pre-service teachers' skills and knowledge of instructional video production lend further support to the growing enthusiasm regarding the potential for this innovative methodology to promote learning in teacher education. It is also believed that pre-service teachers should be provided with the knowledge and skills concerning the characteristics of the flipped learning method and its use in teaching students in creating videos.

Since there was a significant difference between the pre-test and post-test scores of the pre-service teachers in the EG $\left(\mathrm{H}_{0} 3\right)$ and $\mathrm{CG}\left(\mathrm{H}_{0} 4\right)$, future studies could examine student engagement within flipped classrooms activities or focus on learners' satisfaction which should be discussed through the lens of experiential learning. Given that the study dealt with a unit in video production, it is believed that further research is needed about the feasibility of the flipped learning method in units concerning different disciplines or subjects.

\section{References}

Abeysekera, L., \& Dawson, P. (2015). Motivation and cognitive load in the flipped classroom: Definition, rationale and a call for research. Higher Education Research \& Development, 34(1), 1-14. https://doi.org/10.1080/07294360.2014.934336

Almodaires, A.A., Alayyar, G.M., Almsaud, T.O., \& Almutairi, F. (2019). The Effectiveness of Flipped Learning: A Quasi-Experimental Study of the Perceptions of Kuwaiti Pre-Service Teachers. International Education Studies, 12(1), 10-23. https://doi.org/10.5539/ies.v12n1p10

Anderson, J., Young, W., \& Franklin, T. (2014). Brief reflections on flipping the college classroom. Journal of the World Universities Forum, 6(3), 21-29. https://doi.org/10.18848/1835-2030/cgp/v06i03/56832

Ayçiçek, B., \& Yanpar Yelken, T. (2018). The Effect of Flipped Classroom Model on Students' Classroom Engagement in Teaching English. International Journal of Instruction, 11(2), 385-398. https://doi.org/10.12973/iji.2018.11226a

Barua, A., Gubbiyappa, K. S., Baloch, H. Z., \& Das, B. (2014). Validation of Feedback Questionnaire on Flipped Classroom (FC) Activity; Journal of Advanced Pharm. Education \& Research, 4(3), 339-349.

Bishop, J. L., \& Verleger, M. A. (2013, June). The flipped classroom: A survey of the research. In ASEE national conference proceedings, Atlanta, GA (Vol. 30, No. 9, pp. 1-18). 
Cabi, E. (2018). The impact of the flipped classroom model on students' academic achievement. International Review of Research in Open and Distributed Learning, 19(3). https://doi.org/10.19173/irrodl.v19i3.3482

Chen, Y., Wang, Y., Kinshuk, \& Chen, N. S. (2014). Is FLIP enough? or should we use the FLIPPED model instead? Computers and Education, 79, 16-27. https://doi.org/ 10.1016/j.compedu.2014.07.004

Chen, Y., Wang, Y., Kinshuk, \& Chen, N.S. (2014). Is FLIP enough? or should we use the Chen, F., Liu, A.M., \& Martinelli, M. (2017). A systematic review of the effectiveness of flipped classrooms in medical education. Medical Education, 51(12), 585-597. https://doi.org/ 10.1111/medu.13272

Cobb, W. N. W. (2016). Turning the classroom upside own: Experimenting with the flipped classroom in American government. Journal of Political Science Education, 12(1), 1-14 https://doi.org/10.1080/15512169.2015.1063437

Cronhjort, M, Filipsson, L., \& Weurlander, M. (2017). Improved engagement and learning in flipped classroom calculus. Teaching Mathematics and Its Applications, 37, 113-121. https://doi.org/10.1093/teamat/hrx007

Engin, M. (2014) Extending the flipped classroom model: Developing second language writing skills through student-created digital videos. Journal of the Scholarship of Teaching and Learning, 14(5), 12-26. https://doi.org/10.14434/josotlv14i5.12829

Flipped Learning Network (FLN). (2014). The four pillars of F-L-I-P [online]. Retrieved from http://fln.schoolwires.net//site/Default.aspx?PageID=92

Fraga, L. M., \& Harmon, J. (2014). The flipped classroom model of learning in higher education: An investigation of preservice teachers' perspectives and achievement. Journal of Digital Learning in Teacher Education, 31(1), 18-27. https://doi.org/10.1080/21532974.2014.967420

Gall, M.D., Gall, J. P., \& Borg, W. R. (2015). Applying educational research: How to read, do, and use research to solve problems of practice (7th ed.). Boston, MA, Pearson.

García-Sánchez, S., \& Santos-Espino, J. M. (2017). Empowering pre-service teachers to produce ubiquitous flipped classes. PROFILE Issues in Teachers' Professional Development, 19(1), 169-185. http://dx.doi.org/10.15446/profile.v19n1.53857

Gilboy, M. B., Heinerichs, S., \& Pazzaglia, G. (2015). Enhancing student engagement using the flipped classroom. Journal of Nutrition Education Behavior, 47(1), 109-114. https://doi.org/10.1016/j.jneb.2014.08.008

Hamdan, N., McKnight, P. E., McKnight, K., \& Arfstrom, K. M. (2014). A Review of Flipped Learning, Flipped Learning Network. Retrieved from https://flippedlearning.org/review

Hattie, J. A., \& Donoghue, G. M. (2016). Learning strategies: A synthesis and conceptual model. NPJ Science of Learning, 1(1), 1-13. https://doi.org/10.1038/npjscilearn.2016.13

Jeong, J. S., Cañada-Cañada, F., \& González-Gómez, D. (2018). The Study of Flipped-Classroom for Pre-Service Science Teachers Education Science, 8, 163. https://doi.org/10.3390/educsci8040163

Jungic, V., Kaur, H., Mulholland, J., \& Xin, C. (2015). On flipping the classroom in large first year calculus courses. International Journal of Mathematical Education in Science and Technology, 46, 508-520. https://doi.org/10.1080/0020739x.2014.990529

Kolb, D. A. (1984). Experiential Learning: Experience as the Source of Learning and Development. Prentice-Hall, Inc., Englewood Cliffs, New Jersey.

Kolb, D. A. (2014). Experiential Learning: Experience as the Source of Learning and Development (2nd ed.) Pearson Education, Upper Saddle River, New Jersey.

Kurt, G. (2017). Implementing the Flipped Classroom in Teacher Education: Evidence from Turkey. Educational Technology \& Society, 20(1), 211-221.

Kwon, J. E., \& Woo, H. R. (2018). The impact of flipped learning on cooperative and competitive mindsets. Sustainability, 10(1), 79. https://doi.org/10.3390/su10010079_

Lai, T., Lin, F. T., \& Yueh, H. (2020). The effectiveness of team-based flipped learning on a vocational high school economics classroom, Interactive Learning Environments, 28(1), 130-141. https://doi.org/10.1080/10494820.2018.1528284

Larcara, M. (2014). Benefits of the Flipped Classroom Model. In J. Keengwe (Ed.), Promoting Active Learning through the Flipped Classroom Model (pp. 132-144). https://doi.org/10.4018/978-1-4666-4987-3.ch007 
Lee, K., \& Lai, Y. (2017). Facilitating higher-order thinking with the flipped classroom model: a student teacher's experience in a Hong Kong secondary school. Research and Practice in Technology Enhanced Learning, 2(8), 1-14. https://doi.org/10.1186/s41039-017-0048-6

Levin, B. B. (2015). The development of teachers' beliefs. In H. Fives, \& M. G. Gill (Eds.), International handbook of research on teachers' beliefs (pp. 48-65). New York, NY: Routledge.

Lumpkin, A., Achen, R. M., \& Dodd, R. K. (2015). Student perceptions of active learning. College Student Journal, 49(1), 121-133.

McCallum, S., Schultz, J., Sellke, K., \& Spartz, J. (2015). An Examination of the flipped classroom approach on college student academic involvement. International Journal of Teaching and Learning in Higher Education, 27, 42-55.

McLaughlin, J. E., Roth, M. T., Glatt, D. M., Gharkholonarehe, N., Davidson, C. A., Griffin, L. M., ... Mumper, R. J. (2014). The flipped classroom: A course redesign to foster learning and engagement in a health professions school. Academic Medicine, 89(2), 236-243. https://doi.org/10.1097/acm.0000000000000086

Naccarato, E., \& Karakok, G. (2015). Expectations and implementations of the flipped classroom model in undergraduate mathematics courses. International Journal of Mathematical Education in Science and Technology, 46, 968-978. https://doi.org/10.1080/ 0020739X.2015.1071440

Ng, E. M. W. (2016). The flipped classroom: Two learning modes that foster two learning outcomes. Issues in Informing Science and Information Technology, 13, 15-23. https://doi.org/10.28945/3462

Nwosisi, C., Ferreira, A., Rosenberg, W., \& Walsh, K. (2016). A Study of the Flipped Classroom and Its Effectiveness in Flipping Thirty Percent of the Course Content. International Journal of Information and Education Technology, 6(5), 348-351. https://doi.org/ 10.7763/IJIET.2016.V6.712

Patrick, F. (2011). Handbook of Research on Improving Learning and Motivation.

Pierce, R., \& Fox, J. (2012). Vodcasts and Active-Learning Exercises in a "Flipped Classroom" Model of a Renal Pharmacotherapy Module. American Journal of Pharmaceutical Education, 76(10), 196. https://doi.org/10.5688/ajpe7610196

Prince, M. (2004). Does active learning work? A review of the research. Journal of Engineering Education, 93(3), 223-231. https://doi.org/10.1002/j.2168-9830.2004.tb00809.x

Rateau, R. J., Kaufman, E. K., \& Cletzer, D. A. (2015). Innovative classroom strategies that prepare college graduates for workplace success. Journal of Agricultural Education, 56(3), 52-68. https://doi.org/10.5032/jae.2015.03052

Roehl, A., Reddy, S. L., \& Shannon, G. J. (2013). The flipped classroom: An opportunity to engage millennial students through active learning. Journal of Family and Consumer Sciences, 105(2), 44-49. https://doi.org/10.14307/jfcs105.2.12

Sarantakos, S. (2013). Social Research (2nd ed.). Palgrave Macmillan Hampshire. https://doi.org/10.1007/978-1-137-29247-6

Talbert, R. (2014). Inverting the linear algebra classroom. Primus, 24(5), 361-374. https://doi.org/10.1080/10511970.2014.883457

Tomas, L., Doyle, T., \& Skamp, K. (2019). Are first year students ready for a flipped classroom? A case for a flipped learning continuum. International Journal of Educational Technology in Higher Education, 16(1), 5. https://doi.org/10.1186/s41239-019-0135-4

Vaughan, M. (2014). Flipping the learning: An investigation into the use of the flipped classroom model in an introductory teaching course. Education and Research Perspectives, 41, 25-41.

Vaughn, M. (2015). The flipped classroom: The benefits for preservice teachers. In D. Rutledge, \& D. Slykhuis (Eds.), Proceedings from SITE 2015-Society for Information Technology \& Teacher Education international conference (pp. 2622-2624). Las Vegas, NV: Association for the Advancement of Computing in Education.

Weurlander, M., Cronhjort, M., \& Filipsson, L. (2017). Engineering students' experiences of interactive teaching in calculus. Higher Education Research and Development, 36(4), 852-865. https://doi.org/10.1080/07294360.2016.1238880

White, H., \& Sabarwal, S. (2014). Quasi-experimental Design and Methods, Methodological Briefs: Impact 
Evaluation, 8. UNICEF Office of Research, Florence.

Wood, A. K., Galloway, R. K., Sinclair, C., \& Hardy, J. (2018). Teacher-student discourse in active learning lectures: case studies from undergraduate physics. Teaching in Higher Education, 23(7), 818-834. https://doi.org/10.1080/13562517.2017.1421630

Wurdinger, S. D., \& Carlson, J. A. (2010). Teaching for experiential learning: Five approaches that work. Lanham, MD: Rowman \& Littlefield Education.

Yoshida, H. (2016). Perceived Usefulness of "Flipped Learning" on Instructional Design for Elementary and Secondary Education: With Focus on Pre-service Teacher Education. International Journal of Information and Education Technology, 6(6), 430-434. https://doi.org/10.7763/ijiet.2016.v6.727

Yough, M., Merzdorf, H. E., Fedesco, H. N., \& Cho, H. J. (2019). Flipping the classroom in teacher education: Implications for motivation and learning. Journal of Teacher Education, 70(5), 410-422. https://doi.org/10.1177/0022487117742885

\section{Copyrights}

Copyright for this article is retained by the author(s), with first publication rights granted to the journal.

This is an open-access article distributed under the terms and conditions of the Creative Commons Attribution license (http://creativecommons.org/licenses/by/4.0/). 